\title{
PERMEABILITY OF SAND-LIME-CEMENT MIXTURES
}

Mahdi Keramatikerman

Engineer, Arup Australia, 61-73 Sturt Street,

Suncorp Tower, Townsville QLD 4810, Australia

Amin Chegenizadeh

Senior Lecturer, Department of Civil Engineering,

Curtin University of Technology, Kent Street, Bentley, Perth, Western Australia 6102, Australia

Hamid Nikraz

Professor, Department of Civil Engineering,

Curtin University of Technology, Kent Street, Bentley, Perth, Western Australia 6102, Australia

\begin{abstract}
The permeability of mixture of sand and lime was recorded and tested. The constant head method was employed in this study. Different cement contents including $1 \%, 2 \%$, and $3 \%$ in combination with lime with the same percentages were mixed with sand and tested. The permeability test results showed that addition of cement and lime reduced the permeability of the sand.
\end{abstract}

Keywords - Permeability Test, Sand, Lime, Cement

\section{INTRODUCTION}

Permeability is an important characteristic of the soil that shows the rate of flow in the soil [1-13]. The permeability value is high at the coarse-grained soil like sand and is very low at fine-grained soils like clay [14-28]. A high value of permeability can be a representative of a high flow in the soil and therefore a lower strength value for the soil in the long run [29-45]. Addition of cementitious agents such as lime and cement can be effective in reduction of the permeability however its amount is not clear [45-53]. This study investigates effect of addition of cement and lime on permeability characteristics of sand.

\section{MATERIALS}

The materials which were used in this study were:

a) Sand:

The employed sand had $\mathrm{Cu}=8.5$. The $\mathrm{Cc}$ of sand was 1.05. The Gs was 2.65.

\section{b) Lime}

Apparent density was calculated as $0.5 \mathrm{gr} / \mathrm{cm}^{3}$. The ignition loss was $19.8 \%$. c) Cement

Portland cement was selected in this study.

\section{PERMEABILITY TEST}

The tests were conducted in constant head device. The permeability of mixture wre recorded with varying in lime percentage.

\section{$\mathrm{k} \mathrm{cm} / \mathrm{s}$}

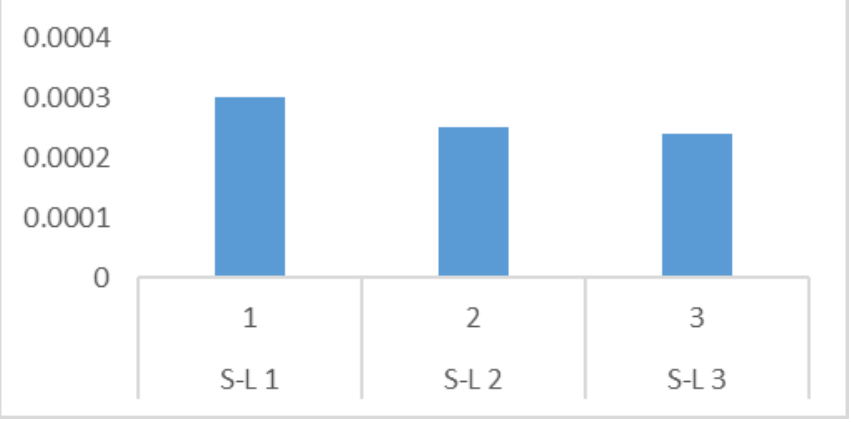

Fig. 1. Permeability of lime-sand mixtures 


\section{International Journal of Engineering Applied Sciences and Technology, 2020 \\ Vol. 4, Issue 11, ISSN No. 2455-2143, Pages 308-311 \\ Published Online March 2020 in IJEAST (http://www.ijeast.com)}

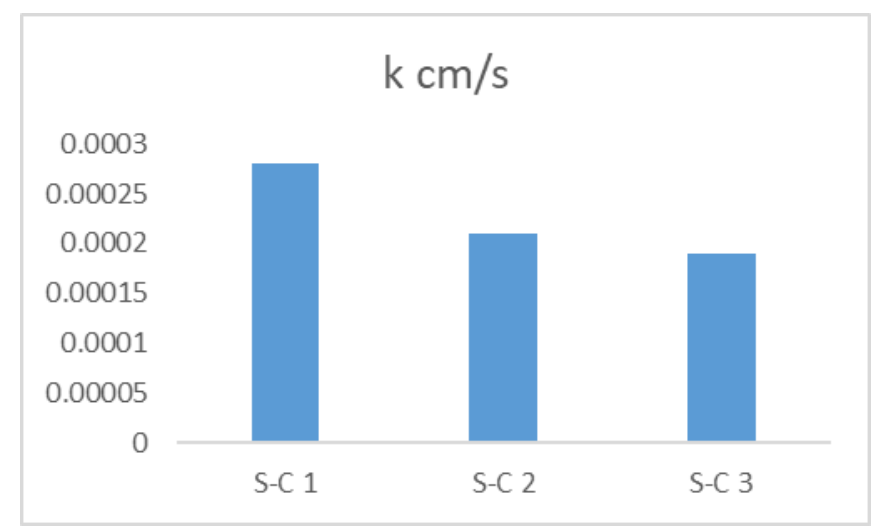

Fig. 2. Permeability of cement-sand mixtures

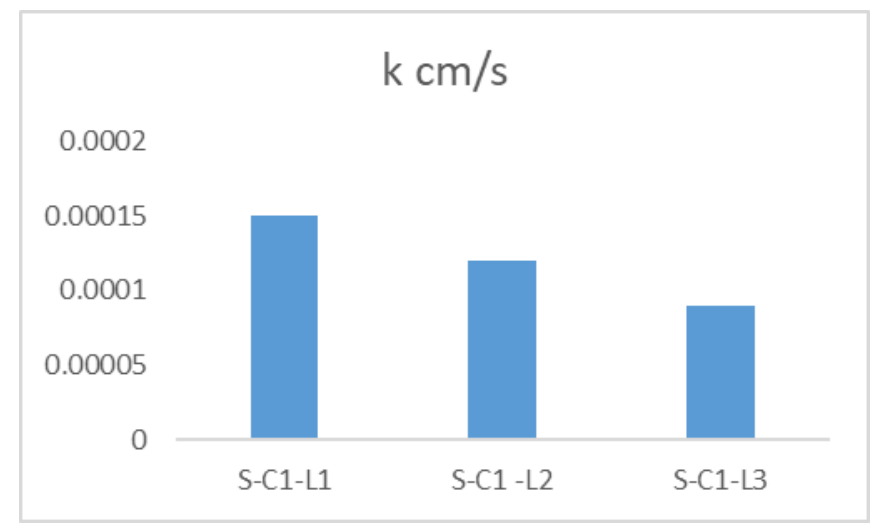

Fig. 3. Permeability of cement-lime sand mixtures with $1 \%$ cement.

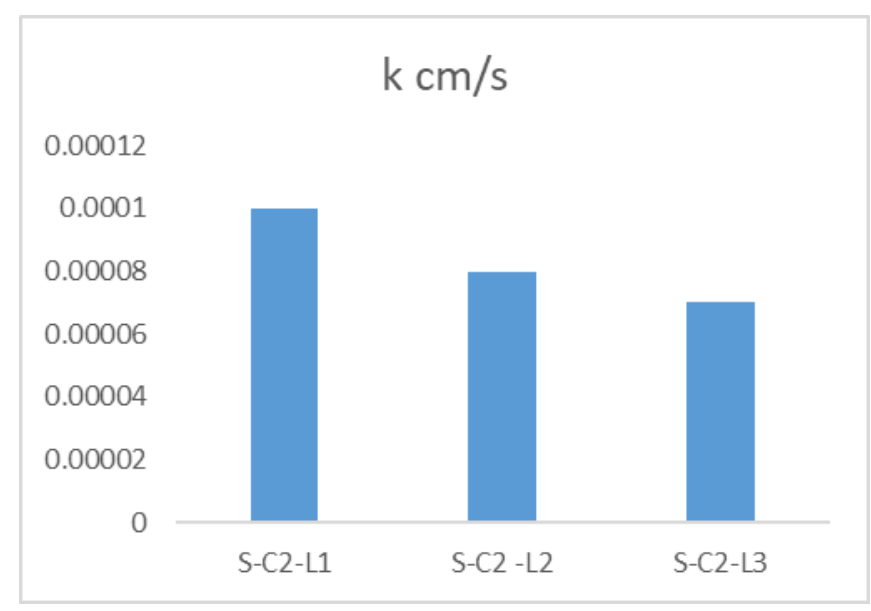

Fig. 4. Permeability of cement-lime sand mixtures with $2 \%$ cement.

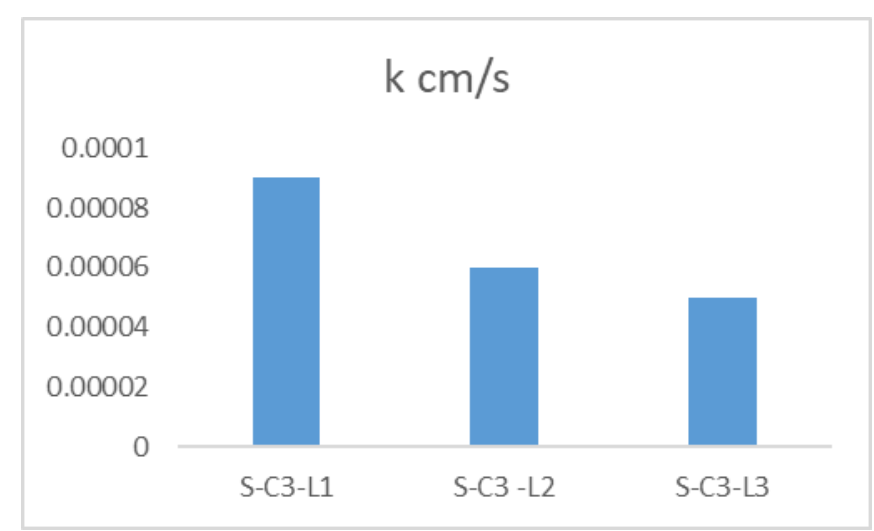

Fig. 4. Permeability of cement-lime sand mixtures with $3 \%$ cement.

\section{CONCLUSION}

A series of permeability tests were conducted on mixtures of cement, lime and sand. Also, permeability tests were conducted individually on cement and lime. The results showed that addition of cement/lime reduced permeability of sand. Also, both cement and lime together decreased the permeability of sand.

\section{REFERENCES}

[1] Shi C. Effect of mixing proportions of concrete on its electrical conductivity and the rapid chloride permeability test (ASTM C1202 or ASSHTO T277) results. Cement and concrete research. 2004 Mar 1;34(3):537-45.

[2] Chegenizadeh A, Aashish M, Nikraz H, Keramatikerman M. Sulphate Attack on Cemented-Bentonite-Coconut Coir. Results in Engineering. 2020 Mar 3:100111.

[3] Ji T. Preliminary study on the water permeability and microstructure of concrete incorporating nano-SiO2. Cement and concrete Research. 2005 Oct 1;35(10):19437.

[4] Chegenizadeh, A., Keramatikerman, M., Miceli, S., Nikraz, H., Salih Sabbar, A. (2020). Investigation on Recycled Sawdust in Controlling Sulphate Attack in Cemented Clay. Appl. Sci., 10, 1441.

[5] Mikhail, M., Chegenizadeh, A., Keramatikerman, M., Burns, G., Terzaghi, S., Nikraz, H. (2020). Application of Cane Ash on Compressive Strength of Soil Uncovered to $\mathrm{MgSO}_{4}$. International Journal of Engineering and Advanced Technology (IJEAT) 9(4).

[6] Haselbach LM, Valavala S, Montes F. Permeability predictions for sand-clogged Portland cement pervious concrete pavement systems. Journal of environmental management. 2006 Oct 1;81(1):42-9.

[7] Chegenizadeh, A., Keramatikerman, M., \& Nikraz, H. (2017). A Study on Numerical Modelling of Rigid Pavement: Temperature and Thickness 


\section{International Journal of Engineering Applied Sciences and Technology, 2020 \\ Vol. 4, Issue 11, ISSN No. 2455-2143, Pages 308-311 \\ Published Online March 2020 in IJEAST (http://www.ijeast.com)}

Effect. International Journal of Civil and Environmental Engineering, 10(2), 265-269.

[8] Halamickova P, Detwiler RJ, Bentz DP, Garboczi EJ. Water permeability and chloride ion diffusion in Portland cement mortars: relationship to sand content and critical pore diameter. Cement and concrete research. 1995 May 1;25(4):790-802.

[9] Mikhail, M., Keramatikerman, M., Chegenizadeh, A., Terzaghi, S., Burns, G., Nikraz, H. (2020). Influence of Bagasse Ash on Compaction Behvaiour of Soil. International Journal of Innovative Technology and Exploring Engineering (IJITEE). 9(5).

[10] Schwarz LG, Krizek RJ. Effect of preparation technique on permeability and strength of cement-grouted sand. Geotechnical Testing Journal. 1994 Dec 1;17(4):434-43.

[11] Al-Rkaby AHJ, Chegenizadeh A, Nikraz H. (2016). Directional-dependence in the mechanical characteristics of sand: A Review International Journal of Geotechnical Engineering 10 (5), 499-509

[12] Chatterji J, Cromwell RS, Reddy BR, King BJ, Nguyen PD, Brown DL, inventors; Halliburton Energy Services Inc, assignee. Methods and compositions for forming permeable cement sand screens in well bores. United States patent US 6,202,751. 2001 Mar 20.

[13] Keramatikerman, M., Chegenizadeh, A., \& Pu, H. (2017). Effect of atrazine contamination on compressibility and permeability characteristics of clay. Geotechnical Testing Journal, 40(6), 936-950.

[14] Keramatikerman, M., Chegenizadeh, A., \& Nikraz, H. (2018). Effect of Flyash on Post-Cyclic Behavior of Sand. Journal of Earthquake Engineering, 1-13.

[15] Chatterji J, Cromwell RS, Reddy BR, King BJ, Nguyen PD, Brown DL, inventors; Halliburton Energy Services Inc, assignee. Methods and compositions for forming permeable cement sand screens in well bores. United States patent US 6,364,945. 2002 Apr 2.

[16] Keramatikerman M, Chegenizadeh A, Terzaghi S. (2019) Review on Effect of Sugarcane Bagasse Ash as an Additive in Construction Industry. 2019. EJGE. Vol.24 Bun. 02.

[17] Nguyen PD, Crook RJ, Barton JA, Brown DL, inventors; Halliburton Energy Services Inc, assignee. Methods and compositions for forming permeable cement sand screens in well bores. United States patent US 6,390,195. 2002 May 21.

[18] Keramatikerman M, Chegenizadeh A. Effect of particle shape on monotonic liquefaction: Natural and crushed sand. Experimental Mechanics. 2017 Oct 1;57(8):1341-8.

[19] Zebovitz S, Krizek RJ, Atmatzidis DK. Injection of fine sands with very fine cement grout. Journal of geotechnical engineering. 1989 Dec;115(12):1717-33.

[20] Keramatikerman, M., Chegenizadeh, A., Nikraz, H., \& Sabbar, A. S. (2018). Effect of flyash on liquefaction behaviour of sand-bentonite mixture. Soils and foundations, 58(5), 1288-1296.
[21] Yang Z, Shi X, Creighton AT, Peterson MM. Effect of styrene-butadiene rubber latex on the chloride permeability and microstructure of Portland cement mortar. Construction and Building Materials. 2009 Jun 1;23(6):2283-90.

[22] Keramatikerman, M., Chegenizadeh, A., Yilmaz, Y., \& Nikraz, H. (2018b). Effect of Lime Treatment on Static Liquefaction Behavior of Sand-Bentonite Mixtures. Journal of Materials in Civil Engineering, 30(11), 06018017.

[23] Shi C. Another look at the rapid chloride permeability test (ASTM C1202 or ASSHTO T277). FHWA Resource Center, Baltimore. 2003 Sep.

[24] Keramatikerman M, Chegenizadeh A, Nikraz $H$. (2017). Experimental study on effect of fly ash on liquefaction resistance of sand Soil Dynamics and Earthquake Engineering 93, 1-6

[25] Lim CC, Gowripalan N, Sirivivatnanon V. Microcracking and chloride permeability of concrete under uniaxial compression. Cement and Concrete Composites. 2000 Oct 1;22(5):353-60.

[26] Chegenizadeh, A., Nikraz, H. (2011). "Investigation on strength of fiber reinforced clay" Advanced

Materials Research 261-263, pp. 957-963.

[27] Kuo WY, Huang JS, Lin CH. Effects of organomodified montmorillonite on strengths and permeability of cement mortars. Cement and Concrete Research. 2006 May 1;36(5):886-95.

[28] Chegenizadeh, A. and H. Nikraz, (2011). "Study on modulus of elasticity of reinforced clay" - Advanced Materials Research. 243-249: pp. 5885-5889, 2011.

[29] Chegenizadeh, A. and H. Nikraz, (2011). Composite Soil: Fiber Inclusion and Strength, Journal of Advanced Materials Research 1646

[30] Chegenizadeh, A. and H. Nikraz, (2012). Composite Clayey Sand and Short Fiber, Advanced Materials Research 383, 2764-2769

[31] Keramatikerman M, Chegenizadeh A, Nikraz H. Effect of Slag on Restoration Mechanical Characteristics of Ethanol Gasoline-Contaminated Clay. Journal of Environmental Engineering. 2018 Jul 1;144(7):06018001.

[32] Chegenizadeh, A., Keramatikerman, M., \& Nikraz, H. (2018). Liquefaction resistance of fibre reinforced lowplasticity silt. Soil Dynamics and Earthquake Engineering, 104, 372-377.

[33] Chegenizadeh A, Keramatikerman M, Panizza S, Nikraz H. (2017). Effect of powdered recycled tire on sulfate resistance of cemented clay. Journal of Materials in Civil Engineering. 2017 Oct 1;29(10):04017160.

[34] Chegenizadeh, A., Keramatikerman, M., Dalla Santa, G., \& Nikraz, H. (2018). Influence of recycled tyre amendment on the mechanical behaviour of soilbentonite cut-off walls. Journal of cleaner production, 177, 507-515 


\section{International Journal of Engineering Applied Sciences and Technology, 2020 \\ Vol. 4, Issue 11, ISSN No. 2455-2143, Pages 308-311 \\ Published Online March 2020 in IJEAST (http://www.ijeast.com)}

[35] Huang B, Wu H, Shu X, Burdette EG. Laboratory evaluation of permeability and strength of polymermodified pervious concrete. Construction and Building Materials. 2010 May 1;24(5):818-23.

[36] Amiralian S, Chegenizadeh A, Nikraz H (2012) Laboratory investigation on the effect of lime on compressibility of soil, Proceedings of the International Conference on Civil and Architectural applications (ICCAA'2012) 89-93

[37] Shahidan S, Koh HB, Alansi AS, Loon LY. Strength development and water permeability of engineered biomass aggregate pervious concrete. InMATEC Web of Conferences 2016 (Vol. 47, p. 01007). EDP Sciences.

[38] Chegenizadeh, A., \& Keramatikerman, M. (2017). Mitigating sulphate attacks in geotechnical engineering Hauppauge, New York, USA Nova Science Publishers. (pp. 1-165).

[39] Gesoğlu M, Güneyisi E. Permeability properties of selfcompacting rubberized concretes. Construction and building materials. 2011 Aug 1;25(8):3319-26.

[40] Keramatikerman M, Chegenizadeh A, Nikraz H. Shear strength characteristics of over-consolidated clay treated with ggbfs. Australian Geomechanics Journal. 2018;53(2):141-9.

[41] Mahasneh BZ, Shawabkeh RA. Compressive strength and permeability of sand-cement-clay composite and application for heavy metals stabilization. Am. J. Appl. Sci. 2004;1:1-4.

[42] Chegenizadeh A, Keramatikerman M, Panizza S, Nikraz H. (2017). Effect of powdered recycled tire on sulfate resistance of cemented clay. Journal of Materials in Civil Engineering. 2017 Oct 1;29(10):04017160.

[43] Keramatikerman, M., Chegenizadeh, A., Nikraz, H. How Ground Improvement Addresses the United Nation Sustainable Development Goals: A Review. Current Trends in Civil \& Structural Engineering 5(3): 2020. CTCSE.MS.ID.000613.

DOI: 10.33552/CTCSE.2020.05.000613

[44] Harnsberger BG, inventor; Texaco Inc, assignee. Permeable cement composition and method. United States patent US 3,948,672. 1976 Apr 6.

[45] Amiralian S, Chegenizadeh A, Nikraz H (2012) Laboratory investigation on the compaction properties of lime and fly ash composite, Proceedings of the International Conference on Civil and Architectural applications (ICCAA'2012) 79-83

[46] Keramatikerman, M., Chegenizadeh, A., \& Nikraz, H. (2017). An investigation into effect of sawdust treatment on permeability and compressibility of soil-bentonite slurry cut-off wall. Journal of Cleaner Production, 162, $1-6$.

[47] Chegenizadeh, A., Keramatikerman, M., \& Nikraz, H. (2016). Flexible pavement modelling using Kenlayer. EJGE, 21, 2467-2479.
[48] Chegenizadeh, A., Keramatikerman, M., Nikraz, H., Importance of Microstructural Analysis in Experimental Soil Stabilization. Global Journal of Engineering Science. 4(5): 2020.

[49] Kuhlmann LA, Foor NC. Chloride permeability versus air content of latex modified concrete. Cement, concrete and aggregates. $1984 \mathrm{Jul}$ 1;6(1):11-6.

[50] Al-Rkaby AHJ, Chegenizadeh A, Nikraz H. (2017). Anisotropic strength of large scale geogrid-reinforced sand:experimental study Soils and foundations 57 (4), 557-574

[51] McCarter WJ, Starrs G, Chrisp TM. Electrical conductivity, diffusion, and permeability of Portland cement-based mortars. Cement and Concrete Research. 2000 Sep 1;30(9):1395-400.

[52] Keramatikerman, M. (2018). Investigations into Effect of By-product Binders in Improvement of Cyclic Behaviour of Soil (Doctoral dissertation, Curtin University).

[53] Vesperman KD, Edil TB, Berthouex PM. Permeability of fly ash and fly ash-sand mixtures. InHydraulic Barriers in Soil and Rock 1985 Jan. ASTM International. 